\title{
Pengembangan Sistem Informasi Geografis Kebun Binatang Berbasis Progressive Web Application (PWA) dengan Metode Prototype (Studi Kasus Kebun Binatang Bandung)
}

\author{
Muhammad Fadillah Arsa ${ }^{a, *}$, Atje Setiawan Abdullah $^{a}$, Juli Rejito ${ }^{a}$ \\ a Program Studi Teknik Informatika, Universitas Padjadjaran, Jatinangor, Kabupaten Sumedang 45363, Indonesia
}

\begin{tabular}{|c|}
\hline INFORMASI ARTIKEL \\
\hline $\begin{array}{l}\text { Sejarah Artikel: } \\
\text { Diterima Redaksi: } 09 \text { Juli } 2021 \\
\text { Revisi Akhir: } 30 \text { November } 2021 \\
\text { Diterbitkan Online: } 31 \text { Desember } 2021\end{array}$ \\
\hline KATA KUNCI \\
\hline $\begin{array}{l}\text { Sistem Informasi Geografis, } \\
\text { Progressive Web Application, } \\
\text { Prototype, } \\
\text { Kebun Binatang }\end{array}$ \\
\hline KORESPONDENSI \\
\hline
\end{tabular}

\section{PENDAHULUAN}

Indonesia merupakan negara tropis yang memiliki sumber daya alam yang melimpah serta keanekaragaman hayati seperti keanekaragaman satwa. Indonesia memiliki 300 jenis satwa liar dan berbagai satwa endemik, dengan seratus delapan puluh emapat jenis mamalia, seratus sembilan belas jenis burung, tiga puluh dua jenis reptil, dan seratus empat puluh jenis amfibi yang keberadaannya mulai terancam punah [1]. Satwa-satwa tersebut perlu diberikan perhatian dan perlindungan, karena jika dibiarkan begitu saja maka kemungkinan besar satwa-satwa tersebut akan mengalami kepunahan.

\section{A B $\mathbf{S}$ T $\mathbf{R}$ A $\mathbf{C}$ T}

Kebun binatang merupakan tempat yang memiliki peran strategis terhadap aspek konservasi satwa, sosial ekonomi masyarakat, maupun lingkungan. Kebun Binatang Bandung sebagai salah satu kebun binatang di Indonesia sudah seharusnya dapat dikelola dengan baik dengan memberikan fasilitas pelayanan yang mumpuni. Namun pada saat ini Kebun Binatang Bandung masih belum memiliki fasilitas layanan petunjuk arah, peta, dan informasi satwa yang memadai. Hal tersebut melatarbelakangi adanya penelitian pengembangan aplikasi Sistem Informasi Geografis Kebun Binatang Bandung ini. Tujuannya agar pengunjung Kebun Binatang Bandung dapat lebih mudah dan nyaman dalam menjelajahi kebun binatang, serta bisa mendapatkan informasi lebih dalam mengenai satwa yang dilihatnya. Pengembangan aplikasi menggunakan metode pengembangan perangkat lunak Prototype yang dinilai baik untuk pengembangan aplikasi berskala kecil. Metode Prototype terdiri dari lima tahap pengembangan yakni Communication, Quick Plan, Modeling Quick Design, Construction of Prototype, dan Deployment Develivery \& Feedback. Sementara itu, aplikasi dibuat berbasis Progressive Web Application (PWA) yang mudah diakses namun tetap memberikan fitur-fitur yang menarik layaknya aplikasi native. Hasil pengembangan aplikasi kemudian diujicobakan dengan menggunakan metode System Usability Scale (SUS) dan Retrospective Think Aloud (RTA). Dari hasil pengujian, didapat didapat nilai usabilitas sebesar 81,43 (Skor SUS) yang tergolong ke dalam kategori Acceptable. Dengan demikian dapat disimpulkan bahwa aplikasi ini diterima dan layak untuk digunakan. 
Coblong, Kota Bandung, Jawa Barat, Indonesia. Pada Kebun Binatang Bandung, satwa disimpan di dalam kendang-kandang satwa yang tersebar dikelompokkan sesuai dengan jenis dan asal muasal satwa. Namun fasilitas pelayanan yang diberikan masih kurang maksimal, seperti kurangnya penjagaan kondisi kebersihan, masih kurangnya petunjuk arah, dan kurangnya peta dan informasi satwa [3]. Hal tesebut bisa berakibat pada sulitnya wisatawan dalam menemukan lokasi fasilitas dan kandang satwa yang ada di kebun binatang, serta minimnya ilmu mengenai satwa yang didapatkan setelah berkunjung.

Berdasarkan beberapa masalah diatas, maka peneliti meyakini pentingnya menerapkan pendekatan berbasis teknologi yang dapat turut menyelesaikan beberapa masalah yang ada di Kebun Binatang Bandung, khususnya masalah petunjuk arah, peta, dan informasi satwa. Salah satu teknologi yang dapat digunakan adalah teknologi Global Positioning System (GPS) yang digunakan dalam Sistem Informasi Geografis (SIG) yang memiliki manfaat untuk mencari titik posisi atau rute dari suatu tujuan lokasi [4].

Menurut Bolstad, Sistem Informasi Geografis (SIG) adalah sistem berbasis komputer untuk membantu pengumpulan, pemeliharaan, penyimpanan, analisis, keluaran, dan distribusi data dan informasi spasial [5]. Dengan memanfaatkan sistem informasi geografis, dengan begitu dapat dikembangkan sebuah sistem pengelolaan data yang memiliki atribut spasial dalam bentuk digital yang menyimpan atribut lokasi posisi fasilitas/kandang satwa kebun binatang. Harapannya, proses pemberian informasi seperti peta fasilitas dan kandang satwa di dalam kebun binatang dapat lebih mudah dilakukan.

Berdasarkan latar belakang di atas, peneliti mencoba untuk memberikan solusi dengan melakukan penelitian pengembangan aplikasi Sistem Informasi Geografis Kebun Binatang berbasis Progressive Web Application (PWA).

Adapun metode prototype merupakan metode pengembangan perangkat lunak yang menggunakan pendekatan evolusioner dengan mengatasi kekurangan pemahaman persyaratan pengguna oleh pengembang perangkat lunak di metode lain [6]. Metode prototype juga sudah mengatasi kekurangan metode lain yang mengarah pada kebutuhan untuk mengulang pengembangan aplikasi. Metode prototype memiliki pendekatan adanya pembuatan prototipe perangkat lunak. Prototipe adalah contoh implementasi sistem yang menunjukkan kemampuan fungsional terbatas dan utama dari sistem yang diusulkan. Prototipe perangkat lunak yang telah dibangun kemudian dikirim ke pengguna untuk evaluasi. Prototipe perangkat lunak membantu pengguna menentukan bagaimana fitur akan berfungsi di perangkat lunak versi akhir. Pelanggan dapat memberikan saran dan perbaikan pada prototipe tersebut.

Sedangkan Progressive Web Application (PWA) merupakan konsep pengembangan aplikasi berbasis web yang mengombinasikan sifat-sifat pada aplikasi native, web, dan juga desktop [7]. Aplikasi yang dikembangkan dengan menggunakan PWA dapat memuat fitur-fitur yang dapat dijalankan dalam mode offline menggunakan service workers, sehingga masasalah kondisi jaringan internet yang kurang baik dapat teratasi. Beberapa kelebihan yang diberikan oleh PWA antara lain

120 Muhammad Fadillah Arsa responsive, konektivitas independen, interaktif seperti nativeapps, selalu diperbarui, aman, mudah dipasang, dan mudah diintegrasikan (linkable). PWA dikonfigurasikan dalam sebuah berkas manifest yang berisikan informasi mengenai website termasuk di dalamnya ikon aplikasi, latar belakang layar, warna, dan orientasi layar standar yang digunakan.

Pengembangan aplikasi menggunakan metode pengembangan perangkat lunak Prototype ini dinilai baik untuk pengembangan aplikasi Sistem Informasi Geografis Kebun Binatang yang berskala kecil. Adapun penggunaan Progressive Web Application sebagai basis pengembangan aplikasi juga dinilai akan memberikan nilai positif bagi kualitas aplikasi.

Penelitian mengenai pengembangan sistem informasi geografis yang berhubungan dengan pemetaan satwa pernah dilakukan oleh Efendi et.al [8]. Pemetaan dilakukan untuk memetakan persebaran satwa langka di Indonesia. Salah satu kesamaan output penelitiannya tersebut ialah adanya hasil peta koordinat posisi objek dalam satu peta. Letak perbedaannya ialah pada objek dan tujuan pembuatan sistem, penelitian yang dilakukan Efendi memiliki objek penelitian satwa dilindungi dan bertujuan untuk memetakan persebaran satwa yang dilindungi oleh pemerintah Indonesia, sedangkan penelitian ini memiliki objek penelitian posisi koordinat lokasi satwa dan fasilitas di dalam kebun binatang yang bertujuan untuk memetakan lokasi fasilitas internal kebun binatang.

Selanjutnya terdapat pula penelitian terdahulu yang dilakukan oleh Exactanaya [9] mengenai pembuatan sistem informasi gografis sebaran pendidikan yang memiliki kesamaan dengan penelitian ini hanya pada teknologi layanan peta yang digunakan yakni menggunakan HERE Maps API. Sedangkan untuk objek dan tujuan penelitian tidak memiliki kesamaan.

Ada pula beberapa penelitian terdahulu juga menggunakan metode Prototype sebagai metode pengembangan perangkat lunak yang digunakan. Pada penelitian yang dilakukan oleh Pramita dan Suputra [10] tentang perancangan sistem informasi geografis untuk mengetahui ketersediaan air tanah di Provinsi Bali, metode yang digunakan ialah metode pengembangan perangkat lunak Prototype seperti halnya metode pengembangan yang digunakan pada penelitian ini. Lalu Yusran et.al [11] juga telah melakukan penelitian mengenai pengembangan sistem informasi e-government berbasis webgis dalam pembuatan profil desa yang juga menggunakan metode Prototype. Namun kedua penelitian tersebut memiliki objek penelitian yang berbeda dengan penelitian ini. Kedua penelitian tersebut akan dijadikan salah satu komponen perbandingan untuk mengetahui efektivitas metode Prototype dalam pengembangan sistem informasi geografis.

Kebaruan yang paling menonjol dari penelitian ini dibandingkan dengan penelitian-penelitian yang telah ada sebelumnya ialah gagasan dan objek penelitian yang dilakukan, serta keluaran aplikasi yang dikembangkan. Belum ada penelitian terdahulu yang dipublikasikan di sumber primer yang meneliti mengenai sistem informasi geografis kebun binatang untuk pemetaan dan navigasi lokasi kandang dan fasilitas satwa, serta belum ada pula keluaran aplikasi Sistem Informasi Geografis Kebun Binatang untuk pemetaan lokasi kandang satwa. Aplikasi Sistem Informasi 
Geografis Kebun Binatang berbasis Progressive Web Application pada penelitian ini merupakan publikasi penelitian pertama mengenai pengembangan aplikasi sistem informasi geografis untuk kebun binatang di Indonesia yang berfokus pada pemetaan lokasi kandang satwa dan fasilitas, sistem navigasi petunjuk arah untuk menuju lokasi kandang/fasilitas kebun binatang yang dituju, serta digitalisasi sistem pemberian informasi mengenai satwa kebun binatang.

\section{METODE}

Metodologi penelitian yang digunakan didasari oleh tahap-tahap yang terdapat pada metode pengembangan perangkat lunak Prototype. Terdapat lima tahap pengembangan yang dilakukan pada penelitian ini antara lain tahap communication, quick plan, modeling quick design, construction of prototype, dan deployment delivery \& feedback [12].

\subsection{Tahap Communication}

Tahap communication merupakan tahap komunikasi antara peneliti dengan pelanggan mengenai tujuan pembuatan aplikasi dan identifikasi kebutuhan aplikasi. Pada tahap ini, peneliti melakukan komunikasi secara langsung terhadap pelanggan yakni pengelola Kebun Binatang Bandung. Proses komunikasi dilakukan dengan metode wawancara untuk menggali informasi mengenai keinginan pihak pengelola Kebun Binatang Bandung terhadap fitur utama dari Sistem Informasi Geografis Kebun Binatang Bandung yang akan dikembangkan. Adapun hasil komunikasi tersebut tercantum pada Tabel 1.

Tabel 1. Hasil Wawancara Kebutuhan Fitur Aplikasi

\begin{tabular}{lll}
\hline No. & \multicolumn{1}{c}{ Usulan Fitur } & Tingkat Kebutuhan \\
\hline 1 & $\begin{array}{l}\text { Peta Koordinat Fasilitas dan } \\
\text { Kandang Satwa }\end{array}$ & Sangat Dibutuhkan \\
2 & $\begin{array}{l}\text { Petunjuk Jalan Menuju } \\
\text { Fasilitas dan Kandang Satwa }\end{array}$ & Sangat Dibutuhkan \\
3 & $\begin{array}{l}\text { Detail Informasi Fasilitas dan } \\
\text { Kandang Satwa }\end{array}$ & Sangat Dibutuhkan \\
4 & $\begin{array}{l}\text { Ulasan Pelanggan Terhadap } \\
\text { Fasilitas dan Kandang Satwa }\end{array}$ & Sangat Dibutuhkan \\
5 & $\begin{array}{l}\text { Scan QR Code Detail } \\
\text { Informasi Fasilitas dan }\end{array}$ & \\
& $\begin{array}{l}\text { Kandang Satwa } \\
\text { Berita atau Artikel Dibutuhkan }\end{array}$ \\
7 & $\begin{array}{l}\text { Laman-laman Deskriptif } \\
\text { Pendukung Aplikasi }\end{array}$ & Sangat Dibutuhkan \\
8 & $\begin{array}{l}\text { Rute Perjalanan } \\
\text { Informasi Tempat-tempat }\end{array}$ & Sangat Dibutuhkan \\
& $\begin{array}{l}\text { Feeding, Tunggangan, dan } \\
\text { Foto Satwa }\end{array}$ & \\
\hline
\end{tabular}

\subsection{Tahap Quick Plan}

Tahap quick plan merupakan tahap perencanaan aplikasi secara cepat setelah terjalin komunikasi. Perencanaan yang dilakukan berkaitan dengan perencanaan jadwal penelitian, fitur aplikasi, dan analisis kebutuhan sistem. Adapun berdasarkan hasil perencanaan, fitur yang akan dibuat dan terdapat pada hasil pengembangan aplikasi tercantum pada Tabel 2 .
Tabel 2. Perencanaan Fitur Aplikasi

\begin{tabular}{|c|c|c|}
\hline No. & Fitur & Deskripsi \\
\hline 1 & $\begin{array}{l}\text { Peta Koordinat Fasilitas } \\
\text { dan Kandang Satwa }\end{array}$ & $\begin{array}{l}\text { Fitur utama berupa peta geografis } \\
\text { yang menunjukkan titik koordinat } \\
\text { letak fasilitas dan kandang satwa } \\
\text { di Kebun Binatang Bandung. } \\
\text { Fasilitas dan kandang satwa juga } \\
\text { dapat dicari dan disaring untuk } \\
\text { mempermudah penggunaan. }\end{array}$ \\
\hline 2 & $\begin{array}{l}\text { Petunjuk Jalan Menuju } \\
\text { Fasilitas dan Kandang } \\
\text { Satwa }\end{array}$ & $\begin{array}{l}\text { Fitur yang membantu pengguna } \\
\text { mendapatkan petunjuk jalan dari } \\
\text { titik keberadaan menuju titik } \\
\text { fasilitas dan kandang satwa. }\end{array}$ \\
\hline 3 & $\begin{array}{l}\text { Detil Informasi Fasilitas } \\
\text { dan Kandang Satwa }\end{array}$ & $\begin{array}{l}\text { Pengguna dapat melihat detil } \\
\text { informasi dari fasilitas dan } \\
\text { kandang satwa berupa deskripsi, } \\
\text { galeri foto, da penjelasan } \\
\text { pendukung lainnya. }\end{array}$ \\
\hline 4 & $\begin{array}{l}\text { Ulasan Pelanggan } \\
\text { Terhadap Fasilitas dan } \\
\text { Kandang Satwa }\end{array}$ & $\begin{array}{l}\text { Pengguna dapat memberikan } \\
\text { ulasan terhadap fasilitas dan } \\
\text { kandang satwa yang dikunjungi. } \\
\text { Melalui ulasan ini, pengelola } \\
\text { kebun binatang dapat melakukan } \\
\text { evaluasi terhadap layanan yang } \\
\text { diberikan. }\end{array}$ \\
\hline 5 & Rute Perjalanan & $\begin{array}{l}\text { Rute perjalanan merupakan fitur } \\
\text { guide yang membantu pengguna } \\
\text { untuk melakukan perjalanan di } \\
\text { kebun binatang secara terarah } \\
\text { menuju fasilitas yang ada. }\end{array}$ \\
\hline 6 & $\begin{array}{ll}\text { Informasi } & \text { Tempat- } \\
\text { tempat } & \text { Feeding, } \\
\text { Tunggangan, } & \text { dan Foto } \\
\text { Satwa } & \end{array}$ & $\begin{array}{l}\text { Adanya penekanan pada informasi } \\
\text { tempat feeding, tunggangan, dan } \\
\text { foto satwa dalam satu fitur khusus } \\
\text { untuk mengajak pengunjung dapat } \\
\text { lebih dekat dan berinteraksi } \\
\text { dengan satwa. }\end{array}$ \\
\hline 7 & Berita atau Artikel & $\begin{array}{l}\text { Fitur tambahan berupa kumpulan } \\
\text { berita atau artikel. }\end{array}$ \\
\hline 8 & $\begin{array}{l}\text { Laman-laman Deskriptif } \\
\text { Pendukung Aplikasi }\end{array}$ & $\begin{array}{l}\text { Laman-laman pendukung seperti } \\
\text { halaman tentang, cara pembelian } \\
\text { tiket, dan kontak. }\end{array}$ \\
\hline 9 & Halaman Admin & $\begin{array}{l}\text { Halaman admin memungkinkan } \\
\text { seluruh konten dan informasi yang } \\
\text { terdapat di dalam aplikasi bersifat } \\
\text { dinamis sehingga dapat diubah } \\
\text { dan dikelola di masa mendatang. }\end{array}$ \\
\hline
\end{tabular}

\subsection{Tahap Modeling Quick Design}

Tahap modeling quick design merupakan tahap pemodelan aplikasi secara lengkap dalam bentuk gambaran dan sketsa aplikasi yang sesuai dengan kebutuhan pelanggan. Pada tahap ini, dilakukan proses pemodelan UML, basis data, serta sketsa aplikasi secara cepat.

\subsubsection{Unified Modeling Language (UML) Aplikasi}

Unified Modeling Language (UML) adalah sebuah standar pemodelan untuk pembuatan diagram dan spesifikasi yang membantu mempermudah komunikasi dan meningkatkan partisipasi dari semua pemangku kepentingan proyek [13] Melalui pemodelan UML, gambaran mengenai persyaratan, struktur, skenario, dan aliran perilaku pengguna pada aplikasi dapat termodelkan. Pemodelan UML bertujuan sebagai pedoman pengembangan selanjutnya dari aplikasi. 


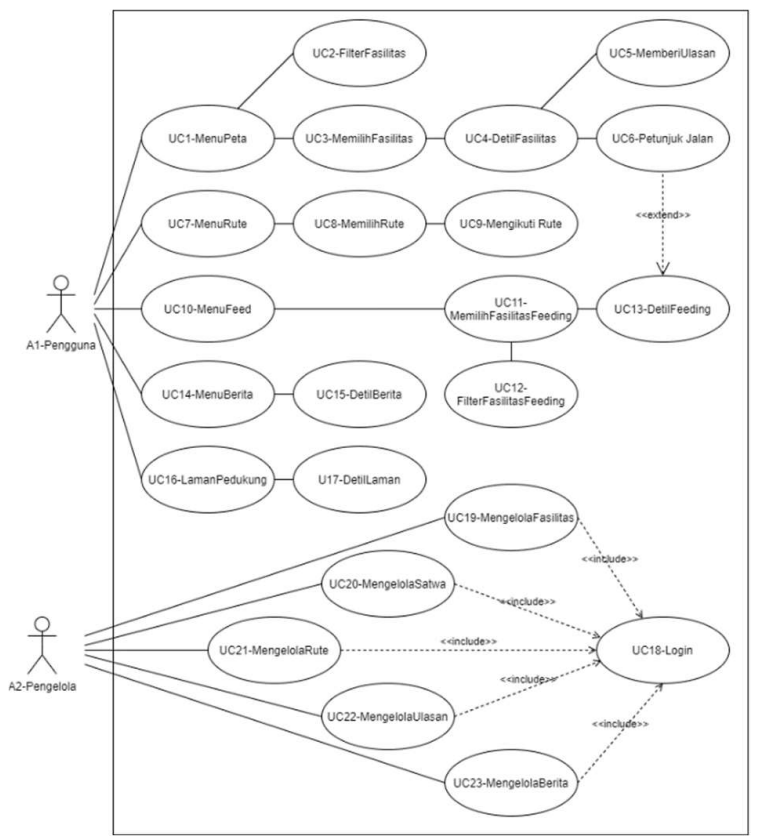

Gambar 1. Use Case Diagram Aplikasi

Gambar 1 menerangkan bahwa aplikasi terdiri dari lima menu yakni peta, rute, feed, berita, dan laman pendukung yang akan digunakan oleh pengguna. Sedangkan pengelola akan menggunakan halaman admin yang berfungsi untuk mengelola seluruh data yang terdapat di dalam aplikasi.

\subsubsection{Basis Data Aplikasi}

Terdapat sembilan tabel pada rancangan basis data yakni tabel facilities, animals, animal_photos, feeds, reviews, users, news, routes, dan route_list yang digambarkan pada Entity Relationship Diagram (ERD) sebagaimana Gambar 2.

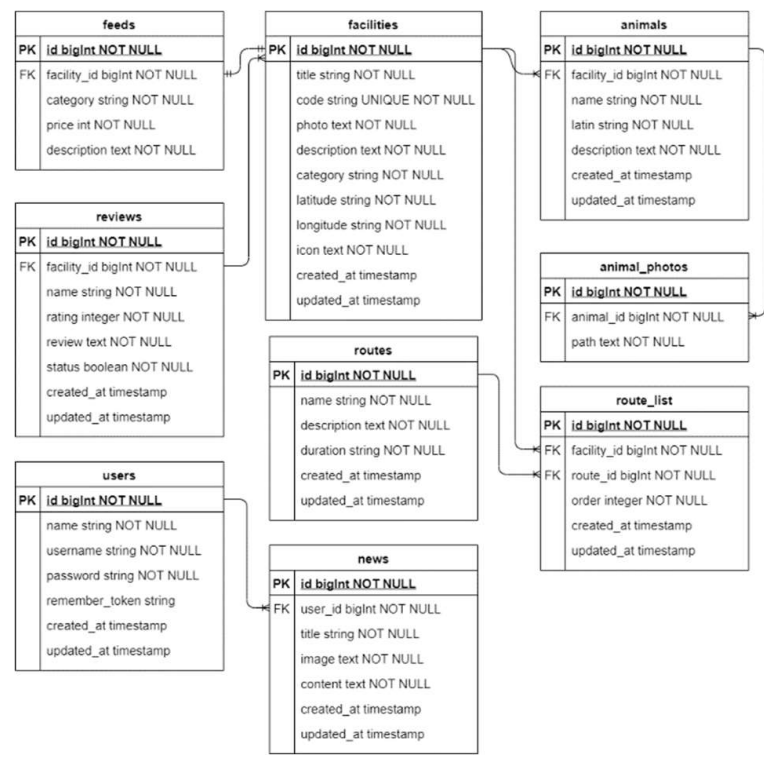

Gambar 2. Entity Relationship Diagram Aplikasi

\subsection{Tahap Construction of Prototype}

Tahap construction of prototype merupakan tahap pembuatan prototipe aplikasi dan pengembangan sistem yang berfokus terhadap evaluasi pelanggan. Pada tahap ini dilakukan

122 Muhammad Fadillah Arsa perancangan dan pembuatan prototipe high-fidelity design, serta pengujian prototipe tersebut.

Pengujian prototipe high-fidelity design dilakukan secara formative dengan usability testing yakni dengan menggunakan metode System Usability Scale (SUS) oleh Brooke. Pengujian dilakukan terhadap responden yang memenuhi kriteria terbiasa menggunakan perangkat smartphone dan memahami teori dasar desain antarmuka dan pengalaman pengguna.

Usability System Scale (SUS) adalah skala sederhana berupa sepuluh item (pertanyaan) yang memberikan pandangan global tentang penilaian subjektif tentang usabilitas [14]. Respon pengguna dalam skala likert lima tingkat: (1) sangat tidak setuju, (2) tidak setuju, (3) ragu-ragu, (4) setuju, dan (5) sangat setuju, kemudian dikonversikan ke dalam perhitungan Skor SUS menurut Brooke sebagaimana persamaan (1) di bawah ini.

$$
\begin{aligned}
\text { Skor SUS }= & \left(\left(q_{1}-1\right)+\left(5-q_{2}\right)+\left(q_{3}-1\right)+\left(5-q_{4}\right)+\right. \\
& \left(q_{5}-1\right)+\left(5-q_{6}\right)+\left(q_{7}-1\right)+\left(5-q_{8}\right)+ \\
& \left.\left(q_{9}-1\right)+\left(5-q_{10}\right)\right) * 2,5
\end{aligned}
$$

Hasil perhitungan SUS kemudian dapat disimpulkan berdasarkan pengukuran skor SUS yang terdiri dari tiga kategori yaitu not acceptable $($ skor $<50)$, marginal $(50 \leq$ skor $<70)$, dan acceptable (skor $\geq 70)[15]$.

Setelah prototipe aplikasi berhasil lolos pengujian, maka selanjutnya Sistem Informasi Geografis Kebun Binatang Bandung diprogram menjadi aplikasi berbasis Progressive Web Application (PWA).

\subsection{Tahap Deployment Delivery \& Feedback}

Tahap deployment delivery \& feedback merupakan tahap menyajikan aplikasi yang siap digunakan oleh pelanggan yang dilanjutkan dengan menilai kepuasan pelanggan atas aplikasi yang telah dibangun. Apabila pelanggan belum puas terhadap hasil aplikasi yang dibangun, selanjutnya dapat dilakukan perulangan proses yaitu kembali melakukan komunikasi.

Pengujian aplikasi yang telah selesai dikembangkan dilakukan menggunakan metode black-box testing untuk menilai fungsionalitas aplikasi dan usability testing jenis summative testing oleh pengguna yakni pengunjung dan pengelola Kebun Binatang Bandung untuk menilai kepuasan pelanggan.

Pengujian fungsionalitas dilakukan untuk menemukan kesalahan dalam sistem. Pengujian fungsionalitas dilakukan oleh minimal tiga puluh orang yang memahami praktik pengembangan aplikasi. Skenario pengujian meliputi seluruh fitur aplikasi yang terdiri dari empat belas skenario fitur pengguna dan delapan skenario fitur pengelola.

Sedangkan pengujian usabilitas oleh pengguna dilakukan secara summative menggunakan metode Usability System Scale (SUS) dan metode Retrospective Think Aloud (RTA). Pengujian metode RTA ini dilakukan dengan mewawancarai responden setelah mencoba aplikasi berdasarkan skenario yang dibuat mengenai aktivitas yang telah dilakukan dan masalah yang dialami [16]. Pengujian usabilitas dilakukan oleh pengunjung Kebun Binatang Bandung dengan mengujikan tujuh skenario fitur pengguna, serta 
dilakukan oleh pengelola Kebun Binatang Bandung yang mengujikan tujuh skenario fitur pengelola.

Hasil pengembangan aplikasi dan hasil pengujian kemudian dipresentasikan kepada pelanggan yakni pengelola Kebun Binatang Bandung untuk mendapatkan feedback. Masukanmasukan yang disampaikan dalam pengujian metode RTA dan wawancara feedback kemudian dihimpun sebagai catatan apabila dilakukan pengembangan lanjutan dari aplikasi.

\section{HASIL DAN PEMBAHASAN}

Proses implementasi yang dilakukan terdiri dari proses pembuatan dan pengujian prototipe, konfigurasi sistem dan implemetasi fitur, pengujian aplikasi, dan wawancara feedback.

\subsection{Hasil Pembuatan dan Pengujian Prototipe Aplikasi}

Prototipe aplikasi dibuat dalam bentuk high-fideltity design yang memiliki kemiripan dan kesesuaian antarmuka dan navigasi dengan aplikasi akhir, sehingga prototipe telah mereprentasikan aplikasi dalam hal antarmuka dan navigasi. Konten seperti gambar fasilitas, deskripsi fasilitas, dan bentuk ikon fasilitas yang terdapat di dalam prototipe juga telah menggunakan konten yang akan digunakan pada aplikasi. Adapun contoh hasil pembuatan prototipe aplikasi dapat dilihat pada Gambar 3.

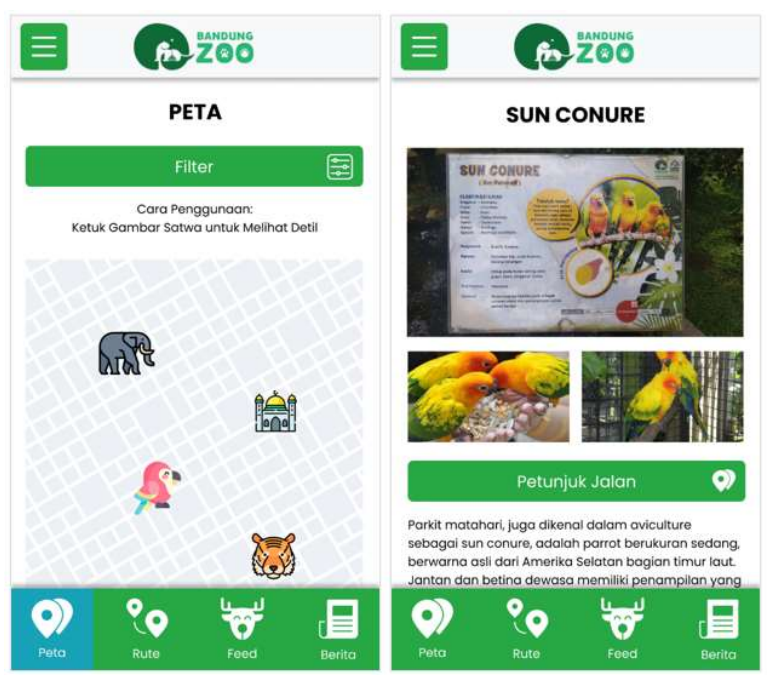

Gambar 3. Hasil Pembuatan Prototipe Aplikasi

Pengujian prototipe aplikasi dilakukan terhadap tiga puluh mahasiswa Prodi S1 Teknik Informatika Universitas Padjadjaran sebagai sasaran yang memenuhi syarat telah terbiasa menggunakan perangkat smartphone dan memahami teori dasar desain antarmuka dan pengalaman pengguna. Pengujian dilakukan secara daring pada tanggal 17, 18, dan 19 April tahun 2021. Adapun hasil pengujian SUS prototipe aplikasi berdasarkan konversi perhitungan SUS dapat dilihat pada Tabel 3.

Dari hasil perhitungan Skor SUS di atas, rata-rata Skor SUS yang didapat adalah 75,83. Berdasarkan tabel pengukuran SUS menurut Brooke, skor tersebut termasuk ke dalam kategori Acceptable dengan Grade Scale C. Dengan demikian, prototipe aplikasi dapat diterima untuk dilakukan proses implementasi.
Tabel 3. Hasil Pengujian SUS Prototipe Aplikasi

\begin{tabular}{|c|c|c|c|c|c|c|c|c|c|c|c|c|}
\hline \multirow{2}{*}{$\begin{array}{c}\text { Kode } \\
\text { Responden } \\
\end{array}$} & \multicolumn{10}{|c|}{ Nilai Hasil Konversi SUS } & \multirow[t]{2}{*}{ Total } & \multirow{2}{*}{$\begin{array}{l}\text { Skor } \\
\text { SUS }\end{array}$} \\
\hline & $q_{1}$ & $q_{2}$ & $q_{3}$ & $q_{4}$ & $q_{5}$ & $q_{6}$ & $q_{7}$ & $q_{8}$ & $q_{9}$ & $q_{10}$ & & \\
\hline $\mathrm{R} 1$ & 3 & 3 & 3 & 4 & 4 & 3 & 3 & 4 & 3 & 4 & 34 & 85 \\
\hline $\mathrm{R} 2$ & 2 & 3 & 2 & 3 & 3 & 3 & 2 & 2 & 2 & 1 & 23 & 58 \\
\hline R3 & 4 & 2 & 3 & 2 & 3 & 1 & 2 & 2 & 4 & 3 & 26 & 65 \\
\hline R4 & 3 & 4 & 4 & 1 & 3 & 4 & 3 & 3 & 4 & 3 & 32 & 80 \\
\hline R5 & 3 & 3 & 4 & 3 & 4 & 0 & 4 & 4 & 4 & 3 & 32 & 80 \\
\hline R6 & 3 & 3 & 3 & 3 & 3 & 1 & 2 & 3 & 3 & 1 & 25 & 63 \\
\hline R7 & 3 & 3 & 3 & 3 & 3 & 2 & 3 & 3 & 3 & 3 & 29 & 73 \\
\hline $\mathrm{R} 8$ & 3 & 3 & 3 & 3 & 2 & 1 & 3 & 3 & 3 & 1 & 25 & 63 \\
\hline R9 & 4 & 3 & 4 & 4 & 4 & 4 & 1 & 4 & 4 & 0 & 32 & 80 \\
\hline R10 & 3 & 3 & 3 & 3 & 2 & 1 & 2 & 3 & 2 & 1 & 23 & 58 \\
\hline R11 & 4 & 3 & 3 & 3 & 4 & 4 & 4 & 4 & 4 & 3 & 36 & 90 \\
\hline R12 & 4 & 3 & 3 & 3 & 3 & 4 & 4 & 3 & 3 & 4 & 34 & 85 \\
\hline R13 & 3 & 3 & 3 & 3 & 4 & 4 & 3 & 4 & 3 & 4 & 34 & 85 \\
\hline R14 & 4 & 4 & 3 & 3 & 4 & 4 & 4 & 4 & 4 & 3 & 37 & 93 \\
\hline R15 & 3 & 2 & 2 & 3 & 2 & 3 & 2 & 3 & 2 & 2 & 24 & 60 \\
\hline R16 & 4 & 3 & 4 & 3 & 4 & 3 & 3 & 4 & 4 & 3 & 35 & 88 \\
\hline R17 & 2 & 1 & 3 & 4 & 1 & 2 & 4 & 3 & 3 & 4 & 27 & 68 \\
\hline R18 & 3 & 3 & 3 & 3 & 4 & 2 & 3 & 3 & 4 & 3 & 31 & 78 \\
\hline R19 & 3 & 1 & 1 & 2 & 2 & 3 & 2 & 2 & 1 & 2 & 19 & 48 \\
\hline R20 & 3 & 3 & 3 & 4 & 3 & 3 & 4 & 4 & 3 & 4 & 34 & 85 \\
\hline R21 & 4 & 4 & 4 & 1 & 4 & 3 & 4 & 4 & 4 & 0 & 32 & 80 \\
\hline R22 & 4 & 3 & 3 & 3 & 4 & 3 & 3 & 3 & 4 & 1 & 31 & 78 \\
\hline R23 & 2 & 1 & 4 & 3 & 2 & 3 & 2 & 4 & 3 & 3 & 27 & 68 \\
\hline R24 & 3 & 4 & 4 & 4 & 3 & 3 & 3 & 3 & 3 & 2 & 32 & 80 \\
\hline R25 & 3 & 3 & 2 & 2 & 3 & 3 & 3 & 4 & 3 & 2 & 28 & 70 \\
\hline R26 & 4 & 3 & 3 & 4 & 4 & 4 & 3 & 4 & 4 & 4 & 37 & 93 \\
\hline R27 & 3 & 3 & 3 & 3 & 3 & 3 & 3 & 3 & 3 & 3 & 30 & 75 \\
\hline R28 & 4 & 4 & 4 & 4 & 4 & 1 & 4 & 4 & 4 & 4 & 37 & 93 \\
\hline R29 & 3 & 3 & 4 & 3 & 3 & 4 & 3 & 3 & 3 & 2 & 31 & 78 \\
\hline R30 & 4 & 3 & 4 & 3 & 3 & 3 & 3 & 3 & 4 & 3 & 33 & 83 \\
\hline \multicolumn{11}{|c|}{ Total Skor SUS } & \multicolumn{2}{|r|}{2275} \\
\hline \multicolumn{11}{|c|}{ Rata-rata Skor SUS } & & 75,83 \\
\hline
\end{tabular}

Pada pengujian prototipe, responden juga diminta untuk memberi masukan. Masukan responden dipetakan dalam severity rating yang dilakukan oleh peneliti yang dianalisis berdasarkan tingkat keparahan masalah usabilitas yang didapatkan. Dari hasil pemetaan masukan responden, guna melakukan perbaikan terhadap nilai usabiltas aplikasi, maka revisi dilakukan untuk setiap masalah yang memiliki severity rating dengan skala 2 (Minor Usability Problem), 3 (Mayor Usability Problem), dan 4 (Usability Catastrophe) sebagaimana Tabel 4[17].

Tabel 4. Revisi Prototipe Aplikasi

\begin{tabular}{llc}
\hline No. & \multicolumn{1}{c}{ Revisi Prototipe } & $\begin{array}{c}\text { Severity } \\
\text { Rating }\end{array}$ \\
\hline 1 & Penambahan Tombol Back & 4 \\
2 & Penjelasan Fitur Rute & 2 \\
3 & Penjelasan Lebih Detil Mengenai Tulisan (1/10) Pada & 2 \\
& Fitur Rute & \\
4 & Penggantian Nama Menu Feed & 4 \\
5 & Penghapusan Menu Login Pada Menu Navigasi Atas & 4 \\
\hline
\end{tabular}

\subsection{Konfigurasi Sistem dan Implementasi Fitur}

Proses pengkodean sistem terbagi menjadi dua tahap, tahap konfigurasi sistem dan implementasi fitur. Konfigurasi sistem diperlukan sebagai konfigurasi awal untuk menyiapkan kebutuhan-kebutuhan yang akan digunakan oleh sistem. Sedangkan pada proses implementasi, perangkat lunak yang digunakan untuk membangun aplikasi ini adalah framework 
Laravel yang mencakup HTML, CSS, bahasa pemrograman PHP, bahasa pemrograman Javascript, serta menggunakan database management system MySQL.

\subsubsection{Konfigurasi Sistem}

Konfigurasi awal sistem yang dilakukan antara lain konfigurasi Laravel, HERE Maps API, melakukan migrasi tabel basis data, dan memasang pustaka pendukung. Beberapa pustaka pendukung yang digunakan pada aplikasi antara lain silviolleite/laravel-pwa, fontawesome, laravel/ui 2.x, laravelcollective/html, startbootstrap-simple-sidebar, dan summernote.

\subsubsection{Implementasi Halaman Admin}

Halaman admin merupakan kumpulan halaman yang akan digunakan oleh pengelola kebun binatang untuk melakukan pengelolaan data aplikasi. Pada halaman admin, terdapat lima halaman menu pengelolaan, yakni pengelolaan fasilitas dan kandang, satwa, rute, ulasan, dan berita. Hak akses untuk masuk ke halaman admin dibatasi oleh sistem login dengan input username dan password admin. Setiap menu pengelolaan memiliki sistem create, read, update, dan delete.

Gambar 4 merupakan tampilan halaman admin indeks data satwa. Halaman indeks berfungsi sebagai halaman untuk menampilkan dan mengelola seluruh data yang telah diinputkan oleh pengelola.

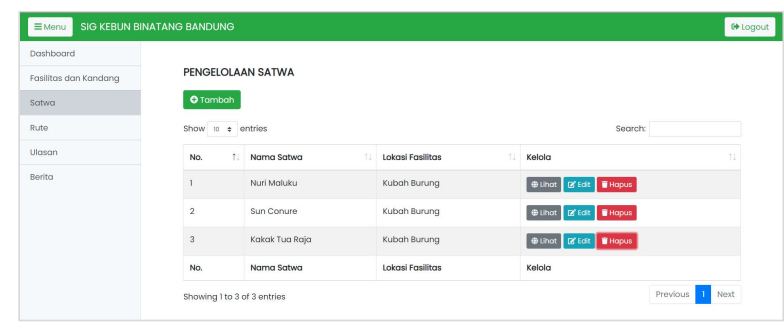

Gambar 4. Tampilan Halaman Admin Indeks Data

Gambar 5 merupakan tampilan halaman admin create data satwa. Halaman create berfungsi untuk menambahkan data ke dalam basis data.

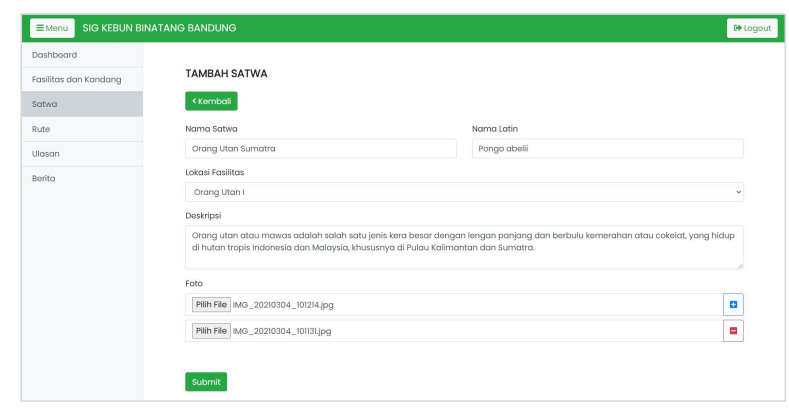

Gambar 5. Tampilan Halaman Admin Create Data

Gambar 6 merupakan tampilan halaman admin edit data satwa. Halaman edit berfungsi untuk mengubah data yang terdapat pada basis data.

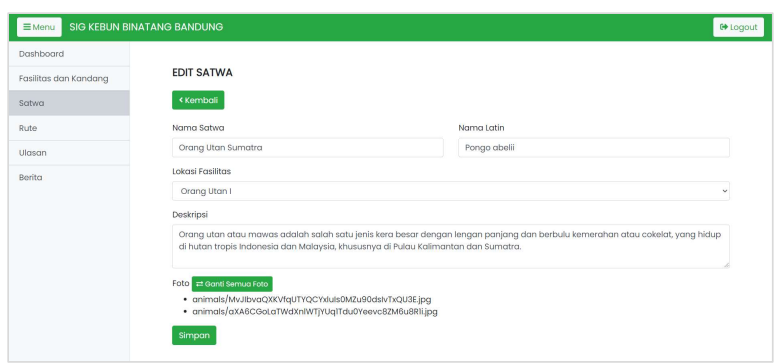

Gambar 6. Tampilan Halaman Admin Edit Data

Gambar 7 merupakan tampilan fungsi delete data satwa. Fungsi delete ditandai dengan adanya popup konfirmasi penghapusan data. Fungsi delete berfungsi untuk menghapus salah satu data yang tersimpan di dalam basis data.

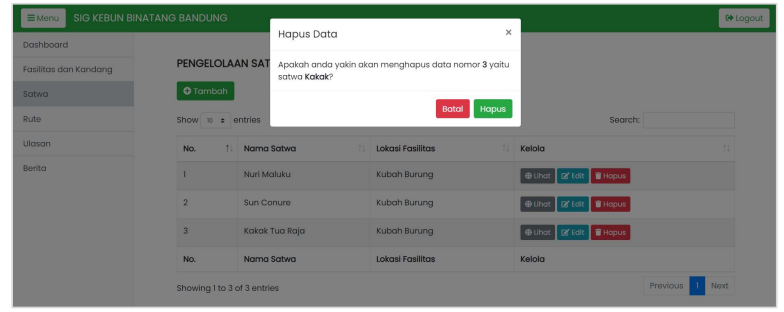

Gambar 7. Tampilan Halaman Admin Delete Data

\subsubsection{Implementasi Fitur Peta}

Fitur peta berisi beberapa fitur aplikasi yang meliputi fitur peta koordinat fasilitas dan kandang satwa, petunjuk jalan menuju fasilitas dan kandang satwa, detil informasi fasilitas dan kandang satwa, dan ulasan pelanggan terhadap fasilitas dan kandang satwa. Fitur peta terletak pada menu peta yang lokasinya beravigasi bawah aplikasi, tepatnya pada menu urutan pertama.

Gambar 8 merupakan tampilan dari halaman menu peta yang berisi ikon-ikon koordinat fasilitas/kandang yang terdapat di Kebun Binatang Bandung.

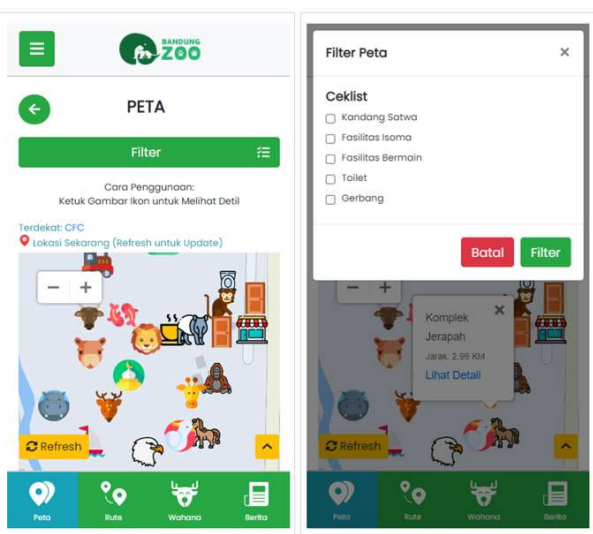

Gambar 8. Tampilan Halaman Menu Peta

Pengembangan tampilan peta dilakukan dengan menggunakan HERE Maps API. HERE Maps API merupakan API berbasis REST APIs, JavaScript APIs, atau Mobile SDK yang dikembangkan oleh HERE untuk menayangkan konten peta permukaan bumi dan lokasi sehingga aplikasi dapat mengintegrasikan suatu peta dan fitur lokasi yang diatur 
sedemikian rupa sesuai dengan kebutuhan ke dalam aplikasi untuk membangun sistem informasi geografis [18].

Fitur peta menampilkan informasi jarak yang didapat dari rumus Great Circle Formula yang merupakan rumus untuk menemukan jarak antara dua titik yang terletak pada garis lintang $\delta$ dan garis bujur $\lambda$ dari $(\delta 1, \lambda 1)$ dan $(\delta 2, \lambda 2)$ pada bola berjari-jari $a$ [19]. Adapun rumus Greate Circle Formula adalah sebagai berikut.

$d=a \cos ^{-1}\left[\cos \delta_{1} \cos \delta_{2} \cos \left(\lambda_{1}-\lambda_{2}\right)+\sin \delta_{1} \sin \delta_{2}\right]$

Setiap fasilitas yang terdapat di dalam peta, memiliki informasi detil fasilitas yang diakses dengan menekan ikon peta sebagaimana tampilan pada Gambar 9. Pada halaman detil inilah, fitur-fitur aplikasi seperti detil satwa, petunjuk jalan, dan mengirim ulasan dapat diakses oleh pengguna.

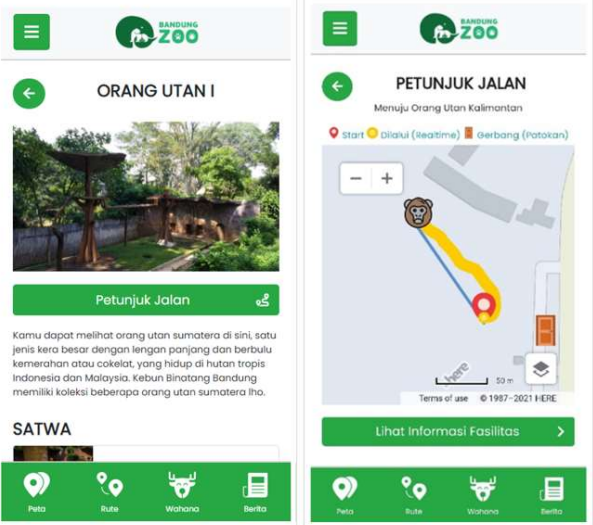

Gambar 9. Tampilan Halaman Detil Fasilitas dan Petunjuk Jalan

\subsubsection{Implementasi Fitur Rute}

Menu rute mencakup merupakan menu yang dapat digunakan oleh pengguna untuk melakukan tour perjalanan mengelilingi Kebun Binatang Bandung. Menu rute terbagi ke dalam beberapa halaman, yakni halaman menu rute, destinasi rute, dan ucapan terima kasih. Gambar 10 merupakan tampilan halaman destinasi rute.

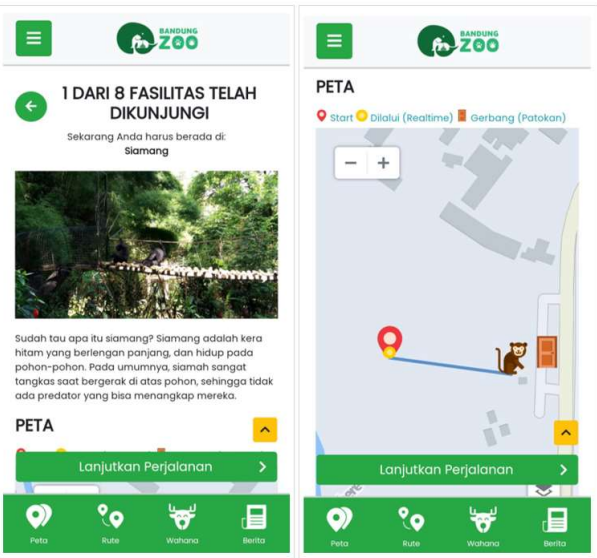

Gambar 10. Tampilan Halaman Destinasi Rute

\subsubsection{Implementasi Fitur Wahana (Feed)}

Menu wahana (feed) merupakan menu yang dapat digunakan oleh pengguna untuk mencari informasi fasilitas feeding, tunggangan, dan foto bersama satwa. Menu wahana (feed) terbagi ke dalam beberapa halaman, yakni halaman menu wahana, detil wahana, dan petunjuk jalan. Fitur wahana juga memiliki tombol petunjuk jalan yang terhubung ke dalam fitur Peta. Gambar 11 merupakan tampilan halaman menu wahana dan detil informasinya.

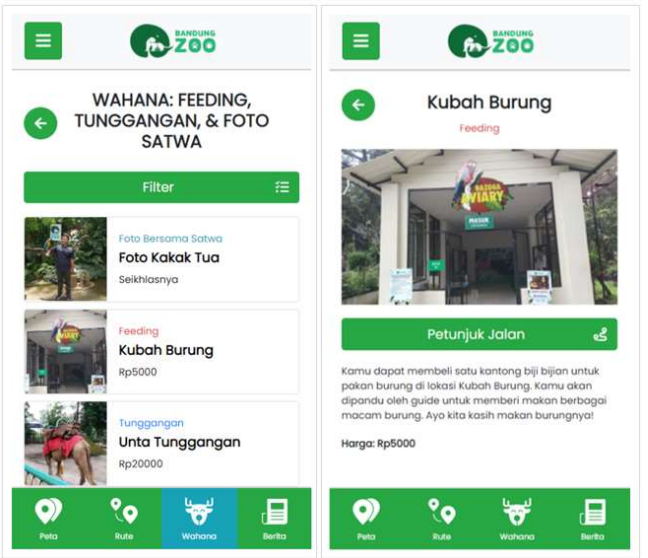

Gambar 11.Tampilan Halaman Menu Wahana dan Detil Informasi

\subsubsection{Implementasi Fitur Berita}

Menu berita memuat kumpulan berita yang perlu dipublikasikan dan diinformasikan kepada pengguna aplikasi. Menu berita hanya terbagi ke dalam dua halaman, yakni halaman menu berita dan detil berita. Gambar 12 merupakan tampilan dari halaman menu berita dan detil berita.

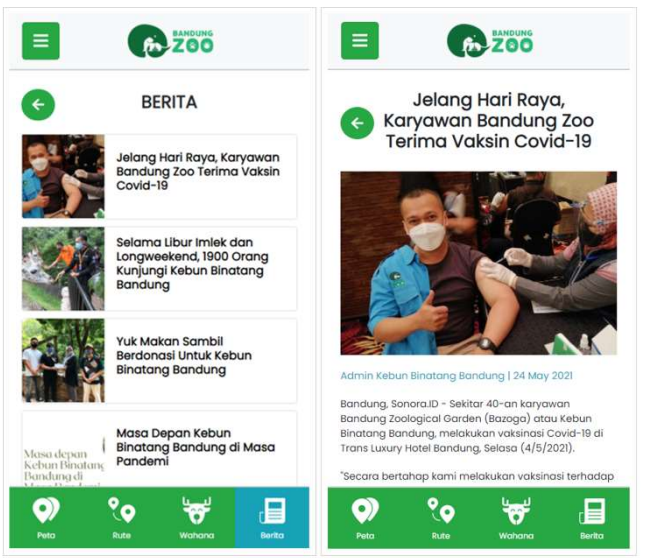

Gambar 12. Tampilan Halaman Menu Berita dan Detil Berita

\subsubsection{Implementasi Laman Pendukung}

Laman-laman pendukung berguna sebagai laman informasi untuk melengkapi aplikasi. Laman pendukung yang terdapat pada aplikasi terdiri dari laman tentang kebun binatang, beli tiket masuk, kontak kami, website utama, dan jasa tour guide. Gambar 13 merupakan tampilan halaman laman pendukung.

\subsubsection{Implementasi PWA}

Implementasi Progressive Web Application pada aplikasi Sistem Informasi Geografis Kebun Binatang Bandung dilakukan dengan menerapkan service worker PWA, mengatur fungsi Add to Home Screen (A2HS) PWA, halaman koneksi terputus, dan mengatur splash screen dan icon aplikasi.

Muhammad Fadillah Arsa 


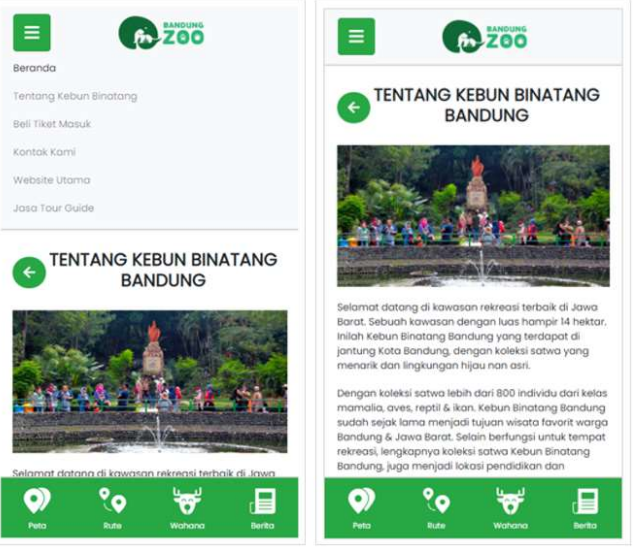

Gambar 13. Tampilan Halaman Laman Pendukung

\subsection{Hasil Pengujian Aplikasi}

Implementasi Progressive Web Application pada aplikasi Sistem Informasi Geografis Kebun Binatang Bandung dilakukan dengan menerapkan service worker PWA, mengatur fungsi Add to Home Screen (A2HS) PWA, halaman koneksi terputus, dan mengatur splash screen dan icon aplikasi.

\subsubsection{Pengujian Fungsionalitas Aplikasi}

Pengujian fungsionalitas aplikasi dilakukan terhadap tiga puluh mahasiswa Prodi S1 Teknik Informatika Universitas sebagai sasaran yang memenuhi syarat memahami praktik pengembangan aplikasi. Pengujian dilakukan untuk mengetahui kesesuaikan setiap skenario pengujian fungsionalitas dengan hasil yang diharapkan menggunakan metode black-box testing. Hasil dari pengujian dipaparkan pada Tabel 5 untuk pengujian fitur pengguna dan Tabel 6 untuk pengujian fitur pengelola.

Tabel 5. Hasil Pengujian Fungsionalitas Aplikasi Fitur Pengguna

\begin{tabular}{|c|c|c|c|}
\hline \multirow[t]{2}{*}{ No. } & \multirow[t]{2}{*}{ Skenario Pengujian } & \multicolumn{2}{|c|}{ Jumlah Responden } \\
\hline & & Sesuai & Tidak Sesuai \\
\hline 1 & $\begin{array}{l}\text { Login admin dengan username dan } \\
\text { password. }\end{array}$ & 30 & 0 \\
\hline 2 & $\begin{array}{l}\text { Melakukan input data fasilitas/kandang } \\
\text { satwa. }\end{array}$ & 30 & 0 \\
\hline 3 & $\begin{array}{l}\text { Melakukan edit data fasilitas/kandang } \\
\text { satwa. }\end{array}$ & 30 & 0 \\
\hline 4 & $\begin{array}{l}\text { Melakukan hapus data fasilitas/kandang } \\
\text { satwa. }\end{array}$ & 30 & 0 \\
\hline 5 & Melakukan input data satwa. & 30 & 0 \\
\hline 6 & Melakukan edit data satwa. & 30 & 0 \\
\hline 7 & Melakukan hapus data satwa. & 30 & 0 \\
\hline 8 & Melakukan input berita. & 30 & 0 \\
\hline 9 & Melakukan edit artikel/ berita. & 30 & 0 \\
\hline 10 & Melakukan hapus artikel/ berita. & 30 & 0 \\
\hline 11 & Menyembunyikan ulasan kandang satwa. & 30 & 0 \\
\hline 12 & Melakukan input rute perjalanan. & 30 & 0 \\
\hline 13 & Melakukan edit rute perjalanan. & 30 & 0 \\
\hline 14 & Melakukan hapus rute perjalanan. & 30 & 0 \\
\hline
\end{tabular}

Berdasarkan hasil pengujian fungsionalitas tersebut, seluruh skenario pengujian fungsionalitas aplikasi, baik untuk fitur-fitur pengelola maupun pengguna, telah sesuai dengan hasil yang diharapkan dan tidak memiliki masalah fungsionalitas.
Tabel 6. Hasil Pengujian Fungsionalitas Aplikasi Fitur Pengelola

\begin{tabular}{llcc}
\hline No. & \multicolumn{1}{c}{ Skenario Pengujian } & $\begin{array}{c}\text { Jumlah Responden } \\
\text { Tidak } \\
\text { Sesuai }\end{array}$ \\
\hline 1 & $\begin{array}{l}\text { Mengakses peta fasilitas dan kandang satwa. } \\
\text { Mengakses detil fasilitas/kandang satwa dan }\end{array}$ & 30 & 0 \\
$\begin{array}{l}\text { melihat petunjuk jalan. } \\
\text { Memberi ulasan fasilitas/kandang satwa. }\end{array}$ & 30 & 0 \\
3 & $\begin{array}{l}\text { Mengakses detil satwa dan melihat petunjuk } \\
\text { jalan. }\end{array}$ & 30 & 0 \\
5 & $\begin{array}{l}\text { Mengakses rute perjalanan dan } \\
\text { menyelesaikan rute. }\end{array}$ & 30 & 0 \\
6 & $\begin{array}{l}\text { Mengakses fasilitas feeding, tunggangan, dan } \\
\text { foto satwa, dan melihat petunjuk jalan. }\end{array}$ & 30 & 0 \\
7 & $\begin{array}{l}\text { Mengakses salah satu berita. } \\
8\end{array}$ & 30 & 0 \\
\hline
\end{tabular}

\subsubsection{Pengujian Usabilitas Aplikasi Metode SUS}

Pengujian usabilitas aplikasi kepada pengunjung Kebun Binatang Bandung dilakukan pada tanggal 2, 3, 5, 6, 12, dan 13 Juni 2021. Sedangkan pengujian kepada pengelola Kebun Binatang bandung dilakukan pada tanggal 8 Juni 2021. Hasil pengujian usabilitas berdasarkan konversi perhitungan metode SUS dapat dilihat pada Tabel 7.

Tabel 7. Hasil Pengujian SUS Aplikasi

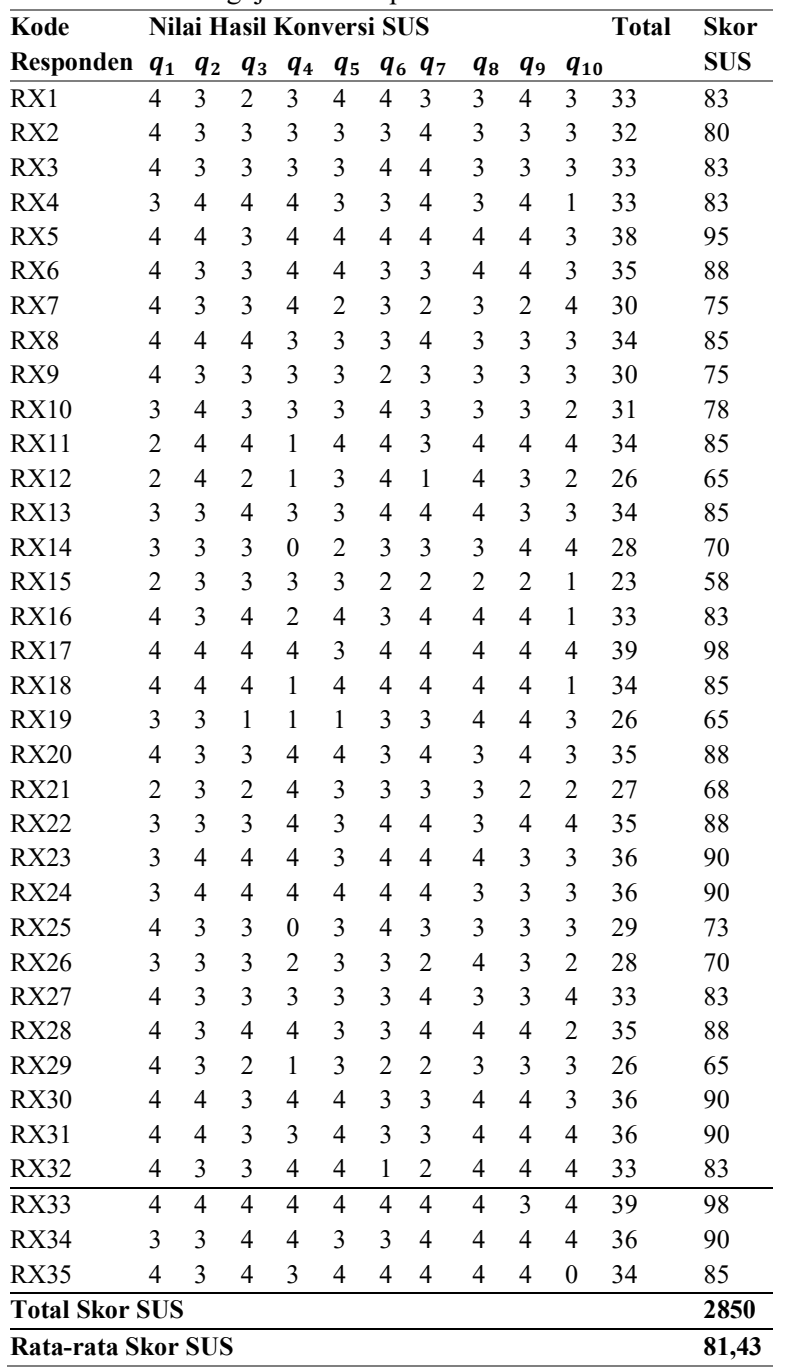


Dari hasil perhitungan Skor SUS, rata-rata Skor SUS yang didapat pada pengujian aplikasi adalah 81,43 . Maka, berdasarkan pengukuran skor SUS menurut Brooke, skor tersebut termasuk ke dalam kategori Acceptable dengan Grade Scale B. Dengan demikian dapat disimpulkan berdasarkan pengujian usabilitas metode SUS ini aplikasi diterima dan layak digunakan secara meluas.

\subsubsection{Pengujian Usabilitas Aplikasi Metode RTA}

Pengujian usabilitas menggunakan metode RTA dilakukan pada tanggal dan responden yang sama dengan pengujian metode SUS. Pengujian metode RTA ini juga dilakukan untuk memperkuat kesimpulan hasil pengujian metode SUS. Hasil dari pengujian metode RTA digunakan sebagai catatan saran feedback pengembangan aplikasi.

\subsection{Feedback}

Feedback/saran untuk aplikasi diambil dari responden pengujian (pengunjung) pada pengujian usabilitas metode RTA dan dari pengelola Kebun Binatang Bandung melalui proses wawancara feedback yang dilakukan pada tanggal 8 Juni 2021. Feedback yang telah diterima dapat digunakan sebagai catatan untuk revisi dan pengembangan lanjutan terhadap aplikasi. Adapun beberapa feedback yang didapat tercantum pada Tabel 8 .

Tabel 8. Feedback Aplikasi

\begin{tabular}{|c|c|c|c|c|}
\hline No. & Kategori & Masukan & Disarankan oleh & Persentase \\
\hline \multirow[t]{4}{*}{1} & Usulan & Penambahan fitur suara lokasi keberadaan pengguna. & Pengelola Kebun Binatang & $2,85 \%$ \\
\hline & Penambahan & Contoh: "Anda sedang berada di Makaw”. & Bandung (RX35) & \\
\hline & Fitur & Penambahan tombol beri ulasan di dalam menu wahana dan rute. & Responden: RX6, RX33 & $5,71 \%$ \\
\hline & & Penambahan tampilan dark mode. & Responden: RX23 & $2,85 \%$ \\
\hline 2 & $\begin{array}{l}\text { Usulan } \\
\text { Pengembangan } \\
\text { Lanjutan }\end{array}$ & $\begin{array}{l}\text { Peta petunjuk jalan dikembangkan lebih lanjut untuk memudahkan } \\
\text { pengguna menemukan fasilitas tujuan. }\end{array}$ & $\begin{array}{l}\text { Responden: RX2, RX3, RX4, RX5, } \\
\text { RX6, RX7, RX8, RX10, RX11, } \\
\text { RX12, RX14, RX15, RX22, RX24, } \\
\text { RX26, RX27, RX28, RX29, RX31 }\end{array}$ & $54,28 \%$ \\
\hline \multirow[t]{3}{*}{3} & $\begin{array}{l}\text { Usulan Revisi } \\
\text { Fitur }\end{array}$ & $\begin{array}{l}\text { Sistem tombol back diubah menjadi mengembalikan ke halaman tingkat } \\
\text { atas (menu). }\end{array}$ & Responden: RX1, RX19, RX30 & $8,57 \%$ \\
\hline & & $\begin{array}{l}\text { Popup detil dibuat menjadi otomatis tertutup ketika membuka popup } \\
\text { lainnya. }\end{array}$ & Responden: RX1, RX6, RX34 & $8,57 \%$ \\
\hline & & Ikon lokasi keberadaan di menu peta dibuat live tanpa harus refresh. & Responden: RX32 & $2,85 \%$ \\
\hline \multirow[t]{3}{*}{4} & Usulan Perbaikan & Perbaikan konten laman: & Responden: RX17, RX27 & $5,71 \%$ \\
\hline & Konten & $\begin{array}{l}\text { - Laman kontak kami diarahkan secara langsung menuju kontak yang } \\
\text { tersedia. }\end{array}$ & & \\
\hline & & $\begin{array}{l}\text { Laman pembelian tiket dijelaskan langsung tahapan pembelian tiketnya. } \\
\text { Pada menu rute, setiap rute diberikan informasi satwa-satwa yang akan } \\
\text { dikunjungi sebelum melakukan perjalanan. }\end{array}$ & Responden: RX17 & $2,85 \%$ \\
\hline
\end{tabular}

\subsection{Ketercapaian Hasil}

Dari segi ketercapaian tujuan pengembangan aplikasi, proses pengembangan aplikasi dapat dikatakan berhasil dilakukan. Dikarenakan berdasarkan hasil pengujian usabilitas aplikasi metode SUS, aplikasi mendapatkan hasil 81,43 Skor SUS kategori Acceptable, maka aplikasi diterima dan telah layak untuk digunakan. Hasil pengujian dan pengembangan aplikasi juga telah dikomunikasikan kepada pihak pengelola Kebun Binatang Bandung dengan keluaran bahwa Kebun Binatang Bandung menerima aplikasi Sistem Informasi Geografis Kebun Binatang berbasis Progressive Web Application sebagai aplikasi yang akan dipergunakan untuk menjadi solusi untuk membantu pengunjung dalam mencari lokasi keberadaan satwa dan mendapat informasi lebih lengkap mengenai satwa di dalamnya.

Lalu untuk melihat efektivitas metode Prototype dalam pengembangan aplikasi terutama pada penelitian ini, maka berikut tersaji tabel perbandingan hasil pengujian dari penelitian ini dengan penelitian sejenis yang telah dilakukan oleh Pramita dan Suputra dan dengan pengelitian yang dilakukan oleh Yusran et.al sebagaimana telah dipaparkan sebelumnya pada bagian pendahuluan. Sebagaimana Tabel 9, hasil pengujian dari masingmasing penelitian menerangkan bahwa metode Prototype terbilang efektif untuk mengembangkan aplikasi sistem informasi geografis karena output yang dikembangkan memiliki hasil pengujian yang baik.
Tabel 9. Perbandingan Hasil Pengujian Penelitian

\begin{tabular}{clc}
\hline No. & \multicolumn{1}{c}{$\begin{array}{c}\text { Penulis dan Judul } \\
\text { Penelitian }\end{array}$} & Hasil Pengujian \\
\hline 1 & [Penelitian Ini] & • Pengujian Black- \\
& Arsa et.al: Pengembangan & box: Seluruh \\
& Sistem Informasi Geografis & Skenario Tercapai \\
& Kebun Binatang Berbasis & • Pengujian SUS: \\
& Progressive Web Application & 81,43 Skor SUS \\
& (PWA) dengan Metode & kategori Acceptable \\
& Prototype (Studi Kasus & \\
& Kebun Binatang Bandung) & \\
\hline 2 & Pramita \& Suputra: Analisis & $\bullet$ Pengujian Black- \\
& Dan Perancangan Sistem & box: Seluruh \\
& Informasi & Skenario Tercapai \\
& Geografis Berbasis Web & \\
& Untuk Mengetahui & \\
& Ketersedian Air Tanah Di & \\
& Provinsi Bali & \\
\hline 3 & Yusran et.al: Rancang & • Pengujian SUS: 83 \\
& Bangun Sistem Informasi & Skor SUS kategori \\
& E-Government & Acceptable \\
Berbasis Webgis Dalam & \\
& Pembuatan Profil Desa & \\
\hline & &
\end{tabular}

Di samping itu, penelitian ini juga telah menghasilkan keluaran aplikasi baru yakni aplikasi Sistem Informasi Geografis Kebun 
Binatang berbasis Progressive Web Application yang berfokus pada pemetaan lokasi kandang satwa dan fasilitas, sistem navigasi petunjuk arah untuk menuju lokasi kandang/fasilitas kebun binatang yang dituju, serta digitalisasi sistem pemberian informasi mengenai satwa kebun binatang, yang sampai jurnal ini ditulis belum ada publikasi dari sumber premier mengenai pembuatan aplikasi sejenis.

\section{KESIMPULAN}

Berdasarkan penelitian yang telah dilakukan, maka didapatkan proses komunikasi yang dilakukan dengan baik terhadap pelanggan yakni pihak pengelola Kebun Binatang Bandung menjadikan proses identifikasi kebutuhan aplikasi dan proses quick plan lebih mudah, akurat, dan cepat untuk dilakukan. Pembuatan model dan sketsa aplikasi pada tahap modeling quick design memberi gambaran secara lengkap mengenai perencanaan aplikasi yang sesuai kebutuhan pelanggan, serta memudahkan peneliti dalam melakukan pembuatan prototype aplikasi. Pengembangan prototype aplikasi yang berfokus terhadap evaluasi pelanggan berhasil dilakukan dan mendapatkan nilai usabilitas pengujian sebesar 75,83 (Skor SUS) kategori Acceptable. Berdasarkan proses deployment delivery \& feedback dan pengujian usabilitas aplikasi kepada pengunjung dan pengelola Kebun Binatang Bandung, aplikasi mendapat nilai sebesar 81,43 (Skor SUS) kategori Acceptable yang berarti aplikasi diterima dan layak untuk digunakan.

\section{DAFTAR PUSTAKA}

[1] N. A. Ramadhan and W. Setyawan, "Ekoturisme: Arsitektur dalam Konservasi Satwa," Jurnal Sains Dan Seni ITS, vol. 7, pp. 116-120, 2018.

[2] A. Puspitasari, B. Masyud, and T. Sunarminto, "Nilai Kontribusi Kebun Binatang Terhadap Konservasi Satwa, Sosial Ekonomi Dan Lingkungan Fisik," Media Konservasi, vol. 21, pp. 116-124, 2016.

[3] C. D. Madya, "Pengembangan Media Interpretasi NonPersonal Untuk Mendukung Wisata Edukasi Pada Area Aves Di Kebun Binatang Bandung," Jurnal Manajemen Resort dan Leisure, vol. 15, pp. 59-73, 2018.

[4] D. Darwis, A. F. Octaviansyah, H. Sulistiani, and Y. R. Putra, "Aplikasi Sistem Informasi Geografis Pencarian Puskesmas Di Kabupaten Lampung Timur," Jurnal Komputer dan Informatika, vol. 15, pp. 159-170, 2020.

[5] P. Bolstad, GIS Fundamentals: A First Text on Geographic Information Systems 6th Edition. Ann Arbor: XanEdu Publishing, 2019, pp. 2-3.

[6] D. Tanwar, "Software Development Models And Their Real Aspects," International Journal of Advance Research in Science and Engineering, vol. 5, pp. 412-421, 2016.

[7] A. A. Kurniawan, "Analisis Performa Progressive Web Application (PWA) Pada Perangkat Mobile," Jurnal Ilmiah Informatika Komputer, vol. 25, pp. 18-31, 2020.

[8] F. S. Efendi, A. Izzah, and Sudarmaji, "Sistem Informasi Geografis Untuk Pendataan Sebaran Satwa Langka Di Indonesia," TEKNOLOGI, vol. 6, pp. 55-60, 2016.

[9] T. A. Exactanaya, A. L. Nugraha, and A. Suprayogi, "Desain Pengembangan Aplikasi Sebaran Pendidikan Berbasis
Webgis Di Kecamatan Demak Kabupaten Demak,” Jurnal Geodesi Undip, vol. 6, pp. 11-20, 2018.

[10] M. D. P. Pramita and I. P. G. H. Suputra, "Analisis Dan Perancangan Sistem Informasi Geografis Berbasis Web Untuk Mengetahui Ketersedian Air Tanah Di Provinsi Bali,” Prosiding Seminar Nasional Teknologi Informasi \&Aplikasinya 2015, vol. 6, pp. 112-119, 2015.

[11] Yusran, P. Purwati, and Z. Sofyan, "Rancang Bangun Sistem Informasi E-Government Berbasis Webgis Dalam Pembuatan Profil Desa," Seminar Nasional APTIKOM (SEMNASTIK) 2019, pp. 108-117, 2019.

[12] R. S. Pressman and B. R. Maxim, Software Engineering: A Practitioner's Approach Ninth Edition. New York: McGraw Hill, 2020, pp. 26-29.

[13] B. Unhelkar, Software Engineering with UML. Boca Raton: CRC Press, 2018, pp. 2-5.

[14] J. Brooke, "SUS - A quick and dirty usability scale," Usability Evaluation in Industry, pp. 4-7, 1996.

[15] J. Brooke, "SUS: A Retrospective," Journal of Usability Studies, vol. 8, pp. 29-40, 2013.

[16] M. A. W. Sadnyana, I. G. M. Darmawiguna, and I. M. A. Pradnyana, "Evaluasi Usability Sistem Informasi Prakerin Pendidikan Teknik Informatika Di Universitas Pendidikan Ganesha Dengan Metode Usability Testing," Kumpulan Artikel Mahasiswa Pendidikan Teknik Inforrmatika (KARMAPATI), vol. 6, pp. 309-319, 2017.

[17] S. Herr, N. Baumgartner, and T. Gross, "Evaluating Severity Rating Scales for Heuristic Evaluation," Conference: the 2016 CHI Conference Extended Abstracts, pp. 3069-3075, 2016.

[18] H. A. Ramadhani, M. Awaluddin, and A. L. Nugraha, "Aplikasi Webgis Untuk Informasi Persebaran Sekolah Menengah Atas Dan Madrasah Aliyah Di Kabupaten Kudus Menggunakan Here Map Api,” Jurnal Geodesi Undip, vol. 5, pp. 164-173, 2016.

[19] V. Jovanović, V. Lazović, and N. Minić, "Sql Query Execution Time Between Two Singidunum University Locations," Synthesis (International Scientific Conference of IT and Business-Related Research), pp. 624-628, 2015.

\section{NOMENKLATUR}

$q \quad$ arti dari pertanyaan $q$

$\mathrm{R} \quad$ arti dari responden $\mathrm{R}$

d arti dari jarak (KM)

a arti dari jari-jari bumi sebesar $6371 \mathrm{KM}$

$\delta \quad$ arti dari titik lintang

$\lambda \quad$ arti dari titik bujur

\section{BIODATA PENULIS}

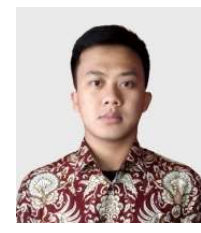

Muhammad Fadillah Arsa

Mahasiswa Program Studi S-1 Teknik Informatika Universitas Padjadjaran angkatan 2017. Kelahiran tahun 1999 dan berdomisili di Bandung. Aktif menekuni bidang pemrograman, kepenulisan, dan bisnis. 
Atje Setiawan Abdullah

Dosen di Program Studi S-1 Teknik Informatika Universitas Padjadjaran. Fokus bidang riset meliputi Data Mining, Decision

Support Systems, dan Knowledge Engineering.

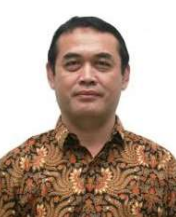

Juli Rejito

Dosen di Program Studi S-1 Teknik Informatika Universitas Padjadjaran. Fokus bidang riset meliputi Database, Image Retrieval, dan Knowledge Engineering. 